\title{
PENINGKATAN KETERAMPILAN MENULIS TEKS DESKRIPSI METODE TTW MEDIA GAMBAR PADA PESERTA DIDIK KELAS VII
}

\author{
Desyarini Puspita Dewi*, Nila Yuniani \\ Program Studi Pendidikan Bahasa dan Sastra Indonesia \\ Fakultas Keguruan dan Ilmu PendidikanUniversitas Pekalongan \\ Korespondensi: desyarini_p_d@yahoo.com
}

\begin{abstract}
The research was motivated by the low interest and value of students in writing descriptive texts in class VII students of SMP N 1 Talun. For this reason, it is necessary to apply learning innovations to improve student achievement. In this study, the think talk write method was applied with the help of image media in the description of text learning materials in the 2013 curriculum., and the second cycle 76.14 increased $18.56 \%$ sufficient in the second cycle because the number of students who have completed has reached $81 \%$. This proves that the application of the think talk write method with the help of pictorial media in learning to write descriptive texts in class VII C SMP N 1 Talun has increased and is effective. The results of observation data in the form of student activities, it was found that in learning there was good communication, in this case there was an interaction between students and teachers and between students.

Based on these results it can be concluded that learning to write descriptive texts using the think talk write method with the help of pictorial media has a significant increase in both the learning process, the average score of writing skills, and changes in student behavior. Class VII C students of SMP $N 1$ Talun after participating in learning to write descriptive text using the think-talk method, writing using pictures as media.
\end{abstract}

Keywords: Improved skill writing text description, Think talk write method, Image media

\section{PENDAHULUAN}

Pembelajaran menulis merupakan keterampilan produktif yang mengharuskan peserta didik mampu menyalurkan ide, gagasan, pesan, dan daya imajinasi yang besar serta menggunakan bahasa yang tepat dan sesuai. Akan tetapi, pada kenyataannya penguasaan bahasa pada peserta didik kelas VII C di SMPN 1 Talun sebagai sasaran untuk meningkatkan penguasaan bahasa yang masih ditemukan kendala. Beberapa kendala yang dihadapi yaitu, kondisi kelas yang kurang kondusif selama proses pembelajaran menjadi faktor pendukung peserta didik tidak menerima materi yang disampaikan oleh guru dengan baik. Dampak dari hal tersebut, peserta didik acuh dan merasa bosan dengan materi yang diberikan. Pada saat peserta didik diberikan tugas menulis teks deskripsi, sering dijumpai hasil pekerjaan yang hampir sama persis satu dengan lainnya tanpa memperhatikan tahapan yang benar seperti memperhatikan kesesuaian isi, penggunaan kata, kerapian dalam menulis, serta kemampuan peserta didik dalam menulis. Kemampuan peserta didik yang masih rendah dalam menulis teks deskripsi dibuktikan pada saat memulai, peserta didik masih kebingungan dikarenakan peserta didik belum menguasai kosa kata yang tepat untuk menulis deskripsi. Hal tersebut menghambat ide atau gagasan peserta didik dalam menulis teks deskripsi yang sesuai dengan struktur dan kaidah kebahasaan. Peserta didik wajib memperhatikan syarat dalam menulis teks deskripsi antara lain, ada struktur yang sesuai, awalan berupa identifikasi atau penentuan sesuai fakta, memiliki alasan yang kuat berdasarkan fakta dan bermanfaat bagi pembaca.

Keterampilan menulis harus dipelajari lebih serius dan pelatihan secara efektif, karena masih banyak peserta didik beranggapan bahwa keterampilan menulis teks adalah keterampilan berbahasa yang paling sulit. Menyebabkan kurangnya minat peserta didik dalam keterampilan menulis. Dalam 
pembelajaran menulis tersebut, perlu diterapkan metode pembelajaran yang efektif dan dapat menunjang pembelajaran peserta didik. Metode yang digunakan sangat bervariasi menyebabkan guru harus lebih selektif dalam memilih metode atau strategi pembelajaran yang sesuai dalam pembuatan teks deskripsi.

Penggunaan metode think talk write yang artinya berpikir, merupakan suatu metode pembelajaran untuk melatih keterampilan peserta didik dalam menulis. Metode ini menekankan peserta didik mengkomunikasikan hasil pemikirannya. Hal ini cukup efektif untuk mendorong dan memotivasi peserta didik dalam menulis teks deskripsi. Dengan menggunakan metode think talk write akan lebih membantu peserta didik menemukan dan mengembangkan dalam meningkatkan kemampuan berbahasa dan menulis teks deskripsi.

Berdasarkan latar belakang di atas, dapat dirumuskan hal sebagai berikut: 1) Bagaimanakah proses pembelajaran menulis teks deskripsi pada peserta didik kelas VII? 2) Bagaimanakah peningkatan keterampilan menulis teks deskripsi metode $T T W$ media gambar pada peserta didik kelas VII? 3) Bagaimanakah perubahan perilaku peserta didik kelas VII setelah mendapat tindakan dengan metode TTW media gambar?

Tujuan penelitian ini yaitu 1) untuk mendeskripsikan proses pembelajaran pembelajaran menulis teks deskripsi pada peserta didik kelas VII. 2) Mendeskripsikan peningkatan keterampilan menulis teks deskripsi pada peserta didik kelas VII. 3) Mendeskripsikan perubahan perilaku peserta didik kelas VII setelah mendapat tindakan dengan metode TTW media gambar.

Berdasarkan hasil observasi dan wawancara dengan guru Bahasa Indonesia kelas VII C semester ganjil SMP N 1 Talun, bahwa nilai pembelajaran peserta didik kelas VII C semester ganjil SMP N 1 Talun dalam keterampilan menulis teks deskripsi masih rendah. Rata-rata nilai menulis teks deskripsi 57,68 sedangkan nilai Kriteria Ketuntasan Minimum (KKM) pelajaran Bahasa Indonesia kelas VII semester ganjil, yaitu 70. Dari jumlah total 35 peserta didik yang tuntas 12 peserta didik atau $34 \%$. Selanjutnya yang tidak tuntas yaitu 23 peserta didik diantaranya 6 peserta didik yang tidak hadir.

\section{KAJIAN PUSTAKA DAN LANDASAN TEORI}

Penelitian yang relevan dengan penelitian ini diantaranya penelitian yang dilakukan oleh Hidayah (2015) yang berjudul Peningkatan Keterampilan Menulis Karangan Deskripsi Melalui Model Think-Talk-Write (TTW) Berbantuan Media Grafis Pada Siswa Kelas IV-A SDN Tambakaji 04 Ngaliyan. Penelitian berikutnya yang relevan ditulis oleh Watara (2016) yang berjudul Peningkatan Kemampuan Menulis Teks Eksposisi Menggunakan Strategi Think Talk Write Pada Siswa Kelas X-MIPA 1 SMA Negeri 1 Temanggung. Penelitian lainnya dari jurnal Diksatrasia (Universitas Galuh Kuningan, Jawa Barat ) volume 1 nomor 2 Agustus 2017 yang ditulis oleh Riswanto (2017) tentang Peningkatan Kemampuan Siswa Menulis Teks Deskriptif Dengan Menggunakan Model Pembelajaran Think Talk And Write. Penelitian lain yang Pengertian menulis dikemukakan oleh Nurgiantoro (2013:422) menyatakan bahwa bahasa memiliki komponen, yakni menyimak, berbicara, membaca, dan menulis. Aktivitas menulis merupakan suatu bentuk menifestasi kompetensi mendengar, berbicara, dan membaca. Menulis merupakan proses pengungkapan ide, gagasan, pikiran, maupun perasaan yang dituangkan melalui tulisan. Kompetensi menulis lebih sulit dibanding tiga kompetensi bahasa yang lain.

Pengertian menulis juga dikemukakan oleh Semi (2007:17) menulis merupakan suatu proses kreatif memindahkan gagasan ke dalam lambang-lambang tulisan. Dalam pengertian ini, menulis itu memiliki tiga aspek utama. Pertama, adanya tujuan atau maksud tertentu yang hendak dicapai. Kedua, adanya gagasan atau sesuatu yang hendak dikomunikasikan. Ketiga, adanya sistem pemindahan gagasan itu yang berupa sistem bahasa.

Alwasilah (dalam Mudrajad 2009:4) menegaskan bahwa menulis merupakan mata pelajaran yang paling diabaikan, baik di 
sekolah lanjutan maupun di perguruan tinggi. Kegiatan menulis merupakan keterampilan berbahasa yang yang paling sulit dikuasai oleh para peserta didik dan mahasiswa juga paling sulit diajarkan oleh para guru dan dosen yang tidak berpengalaman. Kemudian, satu-satunya cara mengajarkan menulis adalah lewat latihan menulis.

Iskandarwassid dan Dadang (2008:248249) menyebutkan bahwa seperti halnya kemampuan berbicara, kemampuan menulis mengandalakan kemampuan berbahasa yang bersifat aktif dan produktif. Kedua keterampilan berbahasa ini merupakan usaha untuk mengungkapkan pikiran dan perasaan yang ada pada diri seorang pemakai bahasa melalui bahasa. Perbedaannya terletak pada cara yang digunankan untuk mengungkapkannya. Penyampaian pesan dalam menulis dilaksanakan secara tertulis.

Teks deskripsi dikemukakan oleh Alwasilah dan Senny (2005:144) deskripsi adalah gambaran verbal ihwan manusia, objek penampilan, pemandangan atau kejadian. Cara penulisan ini menggambarkan sesuatu sedemikian rupa sehingga pembaca dibuat mampu (seolah meraskan, melihat, mendengar, atau mengalami) sebagaimana persepsi oleh panca indra. Deskripsi sangat mengandalkan pencitraan konkret dan rician atau spesifikasi kerena dilandasi pada panca indra.

Teks deskripsi menurut Kokasih (2006:26) teks deskripsi adalah karangan yang menggamabarkan suatu objek dengan tujuan agar pemabaca merasa seolah-olah melihat sendiri objek tersebut yang digambarkan itu. teks deskripsi juga memiliki tujuan sosial untuk menggambarkan suatu objek atau benda secara individual berdasarkan ciri fisiknya. Teks deskripsi juga merupakan tulisan yang menggambarkan atau melukiskan sesuatu yang akan diungkapakan penulis, sehingga pembaca atau yang mendengar belum pernah menyaksikannya sendiri.

Metode pembelajaran yang digunakan untuk melatih keterampilan peserta didik dalam menulis teks deskripsi menggunakan Think Talk Write. Think Talk Write menekankan perlunya peserta didik mengkomunikasikan hasil pemikirannya. Think artinya berpikir. Dalam Kamus Besar Bahasa Indonesia, berpikir artinya menggunakan akal budi untuk mempertimbangkan dan merumuskan sesuatu. Berpikir adalah aktivitas mental untuk dapat merumuskan pengertian, mensintesis, dan menarik simpulan. Berdasarkan pengertian-pengertian di atas, berpikir (think) merupakan kegiatan mental yang dilakukan untuk mengambil keputusan.

Talk artinya berbicara. Dalam kamus besar Bahasa Indonesia, bicara artinya pertimbangan, pikiran, dan pendapat. Write artinya menulis. Menulis adalah membuat huruf (angka dsb). Oleh karena itu, metode think talk write merupakan perencanaan dan tindakan yang cermat mengenai kegiatan pembelajaran, yaitu melalui kegiatan berpikir (think), berbicara/berdiskusi, bertukar pendapat (talk), yaitu menulis hasil diskusi (write) agar kompetensi yang diharapkan tercapai.

Metode TTW ini mempunyai kelebihan sebagai berikut.

a. Mengembangakan pemecahan yang bermakna dalam memahami materi ajar.

b. Dengan menberikan soal open ended dapat mengembangkan keterampilan berpikir kritis dan kreatif peserta didik

c. Dengan berinteraksi dan berdiskusi dengan kelompok akan melibatkan peserta didik secara aktif dalam belajar

d. Membiasakan peserta didik berpikir dan berkomunikasi dengan teman, guru, bahkan dengan diri mereka sendiri.

Kekurangan:

a. Kecuali kalau soal open ended tersebut dapat memotivasi, peserta didik dimungkinkan sibuk.

b. Ketika peserta didik bekerja dalam kelompok itu mudah kehilangan kemampuan dan kepercayaan karena didominasi oleh peserta didik yang mampu.

c. Guru harus benar-benar menyiapkan semua media dengan matang agar dalam menerapkan strategi think talk write tidak mengalami kesulitan. 
Media pembelajaran dikemukakan oleh Azhar (2011:45) media pembelajaran adalah alat bantu pada proses belajar baik di dalam maupun di luar kelas, lebih lanjut dijelaskan bahwa media pembelajaran adalah komponen sumber belajar atau wahana fisik yang mengandung materi intruksional di lingkungan siswa yang dapat merangsang siswa untuk belajar.

\section{METODE PENELITIAN}

Penelitian ini menggunakan desain Penelitian Tindakan Kelas (PTK) yang merupakan suatu pencermatan terhadap kegiatan belajar berupa sebuah tindakan yang sengaja dimunculkan dan terjadi dalam sebuah kelas secara bersamaan dengan tujuan untuk mengadakan perbaikan atau peningkatan mutu praktik pembelajaran di kelas.

Media gambar digunakan untuk memudahkan peserta didik dalam mengingat suatu pembelajaran, karena hal yang didengar akan lebih efektif jika indra penglihatan ikut dilibatkan. Menumbuhkan imajinasi peserta didik untuk memudahkan dalam menulis teks deskripsi. Menurut Hamalik (1986:43) berpendapat bahwa gambar adalah segala sesuatu yang diwujudkan secara visual dalam bentuk dua dimensi sebagai curahan perasaan atau pikiran. Mampu mengembangkan ide dan penggunaan kata yang lebih bervariatif.

PTK menulis teks deskripsi menggunakan TTW media gambar dilaksanakan dalam dua siklus, yaitu proses tindakan pada siklus I dan siklus II. Setiap siklusnya ada empat tahap yaitu perencanaan, tindakan, observasi dan refleksi.

Penelitian ini dilakukan di SMP N 1 Talun Kab. Pekalongan pada peserta didik kelas VII C sebanyak 28 yang dilakukan pada semester gasal tahun ajaran 2019-2020. Data dalam penelitian ini berupa hasil pekerjaan peserta didik dalam kemampuan menulis teks deskripsi.

\section{HASIL DAN PEMBAHASAN}

Penelitian ini menggunakan desain Penelitian Tindakan Kelas (PTK) yang merupakan suatu pencermatan terhadap kegiatan belajar berupa sebuah tindakan yang sengaja dimunculkan dan terjadi dalam sebuah kelas secara bersamaan dengan tujuan untuk mengadakan perbaikan atau peningkatan mutu praktik pembelajaran di kelas. PTK dilaksanakan dalam dua siklus, yaitu proses tindakan pada siklus I dan siklus II. Setiap siklusnya ada empat tahap yaitu perencanaan, tindakan, observasi dan refleksi.

\subsection{Proses Pembelajaran Menulis Teks} Deskripsi Menggunakan Metode Pembelajaran Think Talk Write (TTW) Dengan Media Gambar Pada Peserta Didik Kelas VII C SMP N 1 Talun Kabupaten Pekalongan

Proses pembelajaran menulis teks deskripsi menggunakan metode think talk write dengan media gambar pada siklus I dan siklus II mengalami peningkatan ke arah positif. Hal ini terlihat dari adanya peningkatan menulis teks deskripsi menggunakan metode think talk write dengan media gambar dalam setiap aspek yaitu, proses intensifnya proses internalisasi penumbuhan minat menulis teks deskripsi, proses pembelajaran kondusif tentang cara menulis teks deskripsi menggunakan metode think talk write dengan media gambar, proses peserta didik berlatih menulis teks deskripsi dengan didampingi guru, kondisi peserta didik yang kondusif ketika memaparkan hasil menulis teks deskripsi di depan kelas, dan terbangunnya suasana yang reflektif ketika kegiatan refleksi.

3.2. Peningkatan Keterampilan Menulis Teks Deskripsi Pada Peserta Didik Kelas VII C SMP N 1 Talun Kabupaten Pekalongan Setelah Dilakukan Pembelajaran Menulis Teks Deskripsi Menggunakan Metode Think Talk Write (TTW) Dengan Media Gambar

Persoalan peningkatan keterampilan menulis teks deskripsi dapat dijawab dengan data secara kuantitatif untuk mengetahui peningkatan rata-rata keterampilan peserta didik menulis teks deskripsi dari tahap pra siklus, siklus I, dan siklus II. Pada kegiatan menulis teks deskripsi tahap pra siklus dan siklus I terlihat bahwa keterampilan menulis peserta didik belum memenuhi target yang ditentukan. Hasil menulis teks deskripsi peserta didik belum memenuhi target yang 
ditentukan. Hasil menulis teks deskripsi peserta didik pada tahap prasiklus hanya mencapai 57,58 dari jumlah 28 peserta didik dan siklus I mencapai 69,96 dari 30 peserta didik. Pembelajaran menulis teks deskripsi siklus I walaupun pembelajarannya telah optimal dengan refleksi dan analisis hasil kegiatan di akhir pembelajaran, namun hasilnya belum memuaskan dan belum sesuai target yang diharapkan. Maka dilakuakan siklus II dengan nilai rata-rata 76,14 yang sudah memenuhi nilai KKM yaitu 70 . Tindakan yang dilakukan sampai pada siklus kedua dikarenakan jumlah peserta didik yang sudah yang sudah mencapai KKM atau tuntas telah mencapai target yaitu $81 \%$ dari jumlah 27 peserta didik yang hadir.

Berikut tabel perbandingan hasil menulis teks deskripsi dari Pra Siklus, Siklus 1, dan Siklus 2.

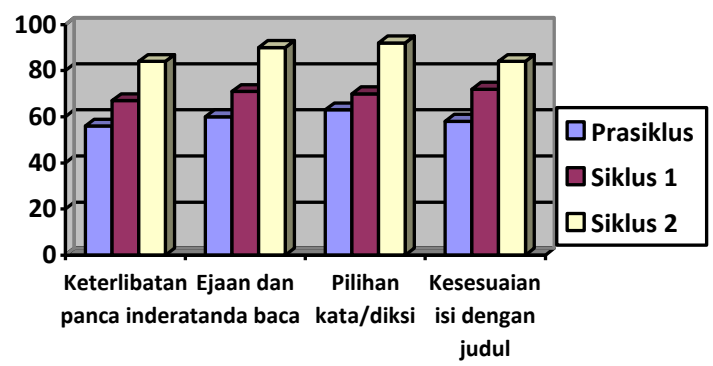

\subsection{Perubahan Perilaku Pada Peserta Didik Kelas VII C SMP N 1 Talun Kabupaten Pekalongan Setelah Mengikuti Pembelajaran Menulis Teks Deskripsi Menggunakan Metode Think Talk Write (TTW) Dengan Media Gambar}

Perubahan perilaku peserta didik setelah mengikuti pembelajaran menulis teks deskripsi menggunakan metode think talk write dengan media gambar dapat dikatan bahwa ada perubahan belajar peserta didik. Dari hasil instrumen nontes melalui observasi siklus I kesiapan peserta didik belum terlihat dan sikap peserta didik dalam menerima materi yang diberikan guru belum fokus. Hal ini dibuktikan dengan kegiatan peserta didik yang berbicara sendiri dengan teman sebangkunya, melamun dan jalan-jalan sendiri tidak mendengarkan penjelasan dari guru. Pada siklus II sudah ada perubahan perilaku peserta didik. Kesiapan peserta didik dalam menerima materi sudah ada. Peserta didik sudah terfokus pada pembelajaran menulis teks deskripsi. Peserta didik menunjukan sikap antusias terhadap pembelajaran menulis teks deskripsi.

Diketahui bahwa peserta didik yang mempunyai minat dan motivasi (antusias, perhatian, dan keseriusan) terhadap pembelajaran sebanyak 20 peserta didik $(66,66 \%)$ pada siklus I dan 25 peserta didik $(92,69 \%)$ pada siklus II dengan jumlah 30 peserta didik. Adapun peserta didik yang aktif (aktif bertanya, respon, dan komentar) sebanyak 10 peserta didik $(33,33 \%)$ dan 23 peserta didik $(81,48 \%)$ pada siklus II dengan jumlah 27 peserta didik.

\section{PENUTUP}

\subsection{Simpulan}

Berdasarkan hasil analisis dan pembahasan penelitian ini, maka dapat disimpulkan sebagai berikut.

a. Proses pembelajaran menulis teks deskripsi menggunakan metode think talk write dengan media gambar pada siklus I dan siklus II mengalami peningkatan ke arah positif. Hal ini terlihat dari adanya peningkatan menulis teks deskripsi menggunkan metode think talk write dengan media gambar pada setiap aspek yaitu aspek yaitu intensifnya penumbuhan minat menulis teks deskripsi, proses penjelasan yang kondusif tentang cara menulis teks deskripsi menggunakan metode think talk write dengan media gambar, proses peserta didik belatih menulis karangan teks deskripsi dengan didampingi guru, kondusifnya kondisi peserta didik ketika memaparkan hasil menulis teks deskripsi di depan kelas, dan terbangunnya suasana kelas yang reflektif ketika refleksi.

b. Keterampilan menulis teks deskripsi menggunakan metode think talk write dengan media gambar pada peserta didik kelas VII C SMP N 1 Talun mengalami peningkatan. Nilai rata-rata yang dicapai peserta didik pada siklus I sebesar 69,96 dan berada pada kategori cukup baik. 
Nilai rata-rata pada siklus I 56,7\% peserta didik yang sudah tuntas, belum mencapai ketuntasan yang telah ditetapkan oleh peneliti sehingga dilakukan siklus II. Pada siklus II nilai rata-rata peserta didik mengalami peningkatan sebesar 76,14 dan berada dalam kategori baik, dicukupkan pada siklus II karena sudah mencapai $81 \%$ peserta didik yang tuntas. Peningkatan nilai rata-rata tersebut membuktikan keberhasilan pembelajaran menulis teks deskripsi menggunakan metode think talk write dengan media gambar.

c. Peningkatan hasil tes juga diikuti oleh perubahan perilaku peserta didik kelas VII C SMP N 1 Talun ke arah yang lebih positif setelah melaksanakan pembelajaran menulis teks deskripsi dengan metode think talk write dengan media gambar. Hal tersebut dapat diketahui dari hasil non tes yang meliputi hasil observasi, jurnal guru, jurnal peserta didik, wawancara, dan dokumentasi foto. Perilaku peserta didik dapat diamati dari karakter yang dimiliki peserta didik yaitu rasa hormat, perhatian, tanggung jawab, dan aktif dalam proses pembelajaran.

\subsection{Rekomendasi}

Beberapa rekomendasi mengenai penggunaan metode TTW dengan media gambar yaitu sebagai berikut:

a) Dalam pembelajaran Bahasa Indonesia, guru hendaknya lebih mengembangkan pembelajaran aspek afektif salah satunya yaitu melalui metode TTW dengan media gambar yang didukung oleh berbagai bahan ajar dengan mengambil tema permasalahan yang terjadi dalam kehidupan dunia nyata peserta didik sehingga mereka lebih tertarik dalam mengikuti proses pembelajaran.

b) Rekomendasi untuk peneliti yang lain yaitu penelitian yang dilakukan dalam penelitian ini hanya mengungkap sebagian kecil permasalahan yang berhubungan dengan proses menulis teks deskripsi. Dalam hal ini masih banyak faktor yang dapat mempengaruhi pada peningkatan keterampilan sdan belum diungkap dalam penelitian ini. Untuk itu disarankan kepada peneliti berikutnya yang berminat melakukan kajian atau penelitian lebih lanjut agar dilaksanakan dengan lebih baik.

\section{DAFTAR PUSTAKA}

Akhaidah, Sabarti. 2004. Pembinaan Kemampuan Menulis Bahasa Indonesia. Jakarta: Erlangga.

Alwasilah, A. Chaedar dan Senny Zuzanna Alwasilah. 2005. Pokoknya Menulis (Cara Baru Menulis Dengan Metode Kolaborasi). Bandung: PT Kiblat Buku Utama.

Azhar, Arsyad. 2011. Media Pembelajaran. Jakarta : Rajawali Pers

Arsyad, Azhar. 2013. Media Pembelajaran. Jakarta: PT. Raja Grafindo Persada.

Hamalik, Oemar. 2003. Proses Belajar Mengajar. Jakarta: Direktorat Jendral Pendidikan Islam Departemen Agama RI.

Hidayah, Muflikhatul. 2015. Peningkatan Keterampilan Menulis Karangan Deskripsi Melalui Model Think-TalkWrite (TTW) Berbantuan Media Grafis Pada Siswa Kelas IV-A SDN Tambakaji 04 Ngaliyan. Skripsi. Universitas Negeri Semarang.

Iskandardarwassid dan Dadang Sunendar. 2008. Strategi Pembelajaran Bahasa. Bandung: PT Remaja Rosdakarya.

Kementrian Pendidikan dan Kebudayaan. 2014. Bahasa Indonesia Ekspresi Diri dan Akademik. Jakarta: Kementrian Pendidikan dan Kebudayaan.

Knapp. Peter and Megan Watkins. 2005. Genre, Text, Grammar: Technologies for Teaching and Assessing Writing. Sydney: Universitiy of New South Wales Press Ltd. 
Kokasih. 2006. Ketatabahasaan dan Kesussatraan. Bandung: CV. YRAMA WIDYA.

Nurgiantoro, Burhan. 2013. Penilaian Pembelajaran Bahasa Berbasis Kompetensi. Yogyakarata: BPFE.

Riswanto, Dede. 2017. Peningkatan Kemampuan Siswa Menulis Teks Deskriptif Dengan Menggunakan
Model Pembelajaran Think Talk And Write. Jurnal. Universitas Galuh.

Semi, M.A. 2 003. Menulis Efektif. Bandung: Angkasa Raya.

Watara, Dwiari Puja. 2016. Peningkatan Kemampuan Menulis Teks Eksposisi Menggunakan Strategi Think-TalkWrite Pada Siswa Kelas X-Mipa 1 Sma Negeri 1 Temanggung. Skripsi. Universitas Negeri Yogyakarta. 